\title{
CHANGES IN MEAN BIRTH WEIGHT AND PROPORTION OF LOW-WEIGHT BIRTHS IN HUNGARY
}

\author{
A. CZEIZEL, M.D. \\ National Institute of Public Health, Budapest \\ Z. BOGNAR, M.D. \\ Medical Unit of Capital Council, Budapest \\ G. TUSNÁDY AND P. RÉVÉSZ \\ Mathematical Research Institute of Hungarian Academy of Sciences
}

The high incidence of low-weight births (not exceeding 2,500g.) is a serious public health problem in Hungary where the deaths of low birth weight babies accounted for $68.4 \%$ of the infant mortality and $83.0 \%$ of the first week mortality in 1967 . The proportion of low-weight births is probably higher in Hungary than in any other European country and appears to be increasing (Table I). The work presented here is an attempt to investigate the reasons for this. It is based on an examination of data recorded in Hungary between 1950 and 1967.

The basic data are presented in Table II. Mean birth weight decreased linearly from 1950 to 1962 and has remained unchanged since (Fig. 1). The proportion of low birth weights increased steadily until 1962.The rate of increase has since slowed down (Fig. 2).

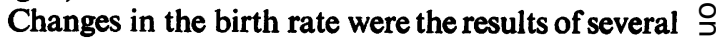
opposing effects (Fig. 3). The post-war increase in birth rate was followed by a decrease in 1951-52. This fall was halted by the 1953 family protection law and by the provision of more stringent penalties for criminal abortion, and a significant increase i $\vec{\theta}$ the number of live births occurred. Following the 1956 measures that made the legal interruption of undesired pregnancies at hospitals possible, the birth rate continued to decrease and reached its lowest level $(12.9$ per 1,000) in 1962. A slight in-

TABLE I

PERCENTAGE FREQUENCY OF LOW-WEIGHT BIRTHS IN VARIOUS COUNTRIES

\begin{tabular}{|c|c|c|c|c|c|c|c|c|}
\hline Year & 1960 & 1961 & 1962 & 1963 & 1964 & 1965 & 1966 & 1967 \\
\hline $\begin{array}{l}\text { Austria } \\
\text { Osterreichisches Statisches Zentralamt }\end{array}$ & $6 \cdot 1$ & $6 \cdot 1$ & - & - & $5 \cdot 8$ & 5.9 & $6 \cdot 1$ & 5.9 \\
\hline $\begin{array}{l}\text { Czechoslovakia } \\
\text { Statistická Rocenka }\end{array}$ & $5 \cdot 8$ & 5.8 & $5 \cdot 7$ & $5 \cdot 8$ & 5.9 & $6 \cdot 1$ & $6 \cdot 3$ & 6.2 \\
\hline $\begin{array}{l}\text { Denmark } \\
\text { Medicinalberetning I. Kalenderarene }\end{array}$ & $5 \cdot 5$ & 5.6 & 5.9 & $5 \cdot 7$ & 5.5 & 5.7 & 5.4 & 5.5 \\
\hline Staatliche Zentralverwaltung für Statistik ${ }^{1}$ & $5 \cdot 1$ & $6 \cdot 3$ & $6 \cdot 0$ & 6.1 & $5 \cdot 8$ & 5.8 & $5 \cdot 5$ & 5.5 \\
\hline Central Statistical Office ${ }^{1}$ & $6 \cdot 7$ & $6 \cdot 7$ & 6.7 & 6.6 & 6.4 & 6.4 & 6.5 & 6.5 \\
\hline $\begin{array}{l}\text { Hungary } \\
\text { KSH., Demographic Yearbooks }\end{array}$ & $9 \cdot 2$ & $9 \cdot 7$ & $10 \cdot 1$ & $10 \cdot 3$ & 10.4 & 10.6 & 10.7 & $10 \cdot 8$ \\
\hline $\begin{array}{l}\text { Central Statistical Office } \\
\text { Poland }\end{array}$ & $4 \cdot 9$ & 4.9 & $5 \cdot 1$ & $5 \cdot 2$ & $5 \cdot 0$ & $5 \cdot 3$ & 5.4 & - \\
\hline $\begin{array}{l}\text { Ministry of Health and Social Welfare' } \\
\text { Sweden }\end{array}$ & 一 & 5.0 & $5 \cdot 3$ & $5 \cdot 3$ & $5 \cdot 3$ & $5 \cdot 6$ & 5.9 & 6.0 \\
\hline $\begin{array}{l}\text { Socialstyrelsen } \\
\text { U.S.A. }\end{array}$ & 4.5 & $4 \cdot 5$ & $4 \cdot 5$ & $4 \cdot 5$ & $4 \cdot 5$ & $4 \cdot 5$ & 4.4 & $4 \cdot 4$ \\
\hline $\begin{array}{l}\text { Natality Statistics Analysis, U.N. }{ }^{1} \\
\text { Yugoslavia }\end{array}$ & $7 \cdot 7$ & $7 \cdot 8$ & $8 \cdot 0$ & $8 \cdot 1$ & $8 \cdot 2$ & $8 \cdot 3$ & $8 \cdot 3$ & $8 \cdot 2$ \\
\hline $\begin{array}{l}\text { Federal Institute for Statistics }{ }^{1} \\
\text { Bosnia and Herzegovina } \\
\text { Montenegro } \\
\text { Croatia } \\
\text { Macedonia } \\
\text { Slovenia } \\
\text { Serbia }\end{array}$ & $\begin{array}{l}7 \cdot 2 \\
5 \cdot 0 \\
5 \cdot 4 \\
7 \cdot 9 \\
5 \cdot 8 \\
7 \cdot 7\end{array}$ & $\begin{array}{l}7 \cdot 1 \\
4.9 \\
7.8 \\
8.4 \\
6.4 \\
8 \cdot 3\end{array}$ & $\begin{array}{l}7.7 \\
5.1 \\
7.1 \\
7.4 \\
6.3 \\
8.1\end{array}$ & $\begin{array}{l}7.6 \\
5.0 \\
6.9 \\
6.9 \\
6.1 \\
8.4\end{array}$ & $\begin{array}{l}8.0 \\
5.3 \\
7.4 \\
7.7 \\
6.2 \\
8.4\end{array}$ & $\begin{array}{l}7.8 \\
5.3 \\
9.0 \\
7.7 \\
8.5\end{array}$ & $\begin{array}{l}= \\
\bar{Z}\end{array}$ & $\begin{array}{l}\text { 二 } \\
\bar{z}\end{array}$ \\
\hline $\begin{array}{l}\text { 1These figures were collected by correspo } \\
\text { Low-weight births are not registered offi }\end{array}$ & & $\begin{array}{c}\text { and on } \\
146\end{array}$ & 1 & rance & & & & \\
\hline
\end{tabular}


TABLE II

ANNUAL BIRTH STATISTICS FOR HUNGARY, 1950-67

\begin{tabular}{|c|c|c|c|c|c|c|c|c|c|c|c|c|c|c|}
\hline \multirow{3}{*}{ Year } & \multirow{3}{*}{$\begin{array}{l}\text { No. of } \\
\text { Live } \\
\text { Births }\end{array}$} & \multicolumn{3}{|c|}{ No. of Live Births at } & \multirow{3}{*}{\begin{tabular}{|c} 
Live \\
Birth \\
Rate \\
per \\
thousand
\end{tabular}} & \multirow{2}{*}{\multicolumn{3}{|c|}{$\begin{array}{l}\text { Incidence of Low- } \\
\text { weight Births }(\%) \text { at }\end{array}$}} & \multirow{3}{*}{$\begin{array}{l}\text { Live } \\
\text { Births } \\
<1,000 \\
\text { g. ( } \% \text { ) }\end{array}$} & \multirow{3}{*}{$\begin{array}{c}\text { No. of } \\
\text { Fetal } \\
\text { Deaths }\end{array}$} & \multirow{3}{*}{$\begin{array}{c}\text { No. of } \\
\text { Induced } \\
\text { Abor- } \\
\text { tions }\end{array}$} & \multicolumn{3}{|c|}{ Mean Birth Weight (g.) at } \\
\hline & & \multirow{2}{*}{ Hospital } & \multirow{2}{*}{ Home } & \multirow{2}{*}{ Total } & & & & & & & & Hospital & 1 Home & Total \\
\hline & & & & & & Hospita & 1 Home & Total & & & & & & \\
\hline $\begin{array}{l}1950 \\
1951 \\
1952 \\
1953 \\
1954 \\
1955 \\
1956 \\
1957 \\
1958 \\
1959 \\
1960 \\
1961 \\
1962 \\
1963 \\
1964 \\
1965 \\
1966 \\
1967\end{array}$ & $\begin{array}{l}199,729 \\
194,360 \\
189,298 \\
210,431 \\
227,023 \\
213,876 \\
195,850 \\
169,714 \\
160,665 \\
153,347 \\
148,418 \\
142,105 \\
131,650 \\
133,986 \\
133,690 \\
134,525 \\
140,004 \\
150,465\end{array}$ & $\begin{array}{r}66,416 \\
78,383 \\
91,786 \\
124,570 \\
139,337 \\
136,787 \\
129,019 \\
115,458 \\
119,751 \\
121,245 \\
124,397 \\
125,899 \\
120,365 \\
125,244 \\
126,631 \\
128,485 \\
134,591 \\
145,156\end{array}$ & $\begin{array}{r}129,151 \\
112,262 \\
94,034 \\
82,356 \\
84,010 \\
73,643 \\
63,791 \\
51,744 \\
38,677 \\
29,949 \\
22,064 \\
14,466 \\
9,727 \\
7,091 \\
5,510 \\
4,524 \\
3,898 \\
3,730\end{array}$ & $\begin{array}{l}195,567 \\
190,645 \\
185,820 \\
206,926 \\
223,347 \\
210,430 \\
192,810 \\
167,202 \\
158,428 \\
151,194 \\
146,461 \\
140,365 \\
130,053 \\
132,335 \\
132,141 \\
133,009 \\
138,489 \\
148,886\end{array}$ & $\begin{array}{l}20 \cdot 9 \\
20 \cdot 2 \\
19 \cdot 6 \\
21 \cdot 6 \\
23 \cdot 0 \\
21 \cdot 4 \\
19 \cdot 5 \\
17 \cdot 0 \\
16 \cdot 0 \\
15 \cdot 2 \\
14 \cdot 7 \\
14 \cdot 0 \\
12 \cdot 9 \\
13 \cdot 1 \\
13 \cdot 1 \\
13 \cdot 1 \\
13 \cdot 6 \\
14 \cdot 6\end{array}$ & $\begin{array}{r}9.62 \\
9.87 \\
9.59 \\
9.68 \\
9 \cdot 12 \\
9.18 \\
9.47 \\
9.84 \\
9.50 \\
9.64 \\
9.77 \\
9.97 \\
10.26 \\
10.36 \\
10.27 \\
10.50 \\
10.55 \\
10.61\end{array}$ & $\begin{array}{r}4 \cdot 02 \\
3 \cdot 68 \\
3 \cdot 41 \\
3 \cdot 78 \\
3 \cdot 47 \\
3.90 \\
4 \cdot 24 \\
4 \cdot 70 \\
4 \cdot 69 \\
5 \cdot 29 \\
5 \cdot 80 \\
7 \cdot 10 \\
8 \cdot 18 \\
9 \cdot 96 \\
12 \cdot 23 \\
13 \cdot 82 \\
14 \cdot 85 \\
18 \cdot 36\end{array}$ & $\begin{array}{r}6 \cdot 01 \\
6 \cdot 22 \\
6 \cdot 46 \\
7 \cdot 33 \\
7 \cdot 00 \\
7 \cdot 33 \\
7 \cdot 74 \\
8 \cdot 25 \\
8 \cdot 33 \\
8 \cdot 78 \\
9 \cdot 17 \\
9 \cdot 68 \\
10 \cdot 11 \\
10 \cdot 33 \\
10 \cdot 35 \\
10 \cdot 61 \\
10 \cdot 67 \\
10 \cdot 81\end{array}$ & $\begin{array}{l}0.16 \\
0.21 \\
0.22 \\
0.31 \\
0.33 \\
0.30 \\
0.29 \\
0.34 \\
0.33 \\
0.39 \\
0.41 \\
0.42 \\
0.45 \\
0.45 \\
0.46 \\
0.58 \\
0.67 \\
0.69\end{array}$ & $\begin{array}{l}38,503 \\
39,958 \\
45,553 \\
43,652 \\
45,842 \\
46,712 \\
44,301 \\
42,142 \\
39,764 \\
37,513 \\
35,825 \\
35,518 \\
35,492 \\
35,701 \\
35,907 \\
35,245 \\
35,147 \\
36,417\end{array}$ & $\begin{array}{r}1,707 \\
1,684 \\
1,715 \\
2,677 \\
16,281 \\
35,398 \\
82,463 \\
123,275 \\
145,578 \\
152,404 \\
162,160 \\
169,992 \\
163,656 \\
173,835 \\
184,367 \\
182,269 \\
186,773 \\
187,527\end{array}$ & $\begin{array}{l}3,189 \\
3,160 \\
3,180 \\
3,164 \\
3,193 \\
3,189 \\
3,178 \\
3,165 \\
3,170 \\
3,163 \\
3,166 \\
3,159 \\
3,145 \\
3,144 \\
3,147 \\
3,145 \\
3,152 \\
3,151\end{array}$ & $\begin{array}{l}3,456 \\
3,434 \\
3,433 \\
3,388 \\
3,410 \\
3,381 \\
3,362 \\
3,338 \\
3,326 \\
3,307 \\
3,281 \\
3,242 \\
3,184 \\
3,133 \\
3,042 \\
3,031 \\
3,012 \\
2,967\end{array}$ & $\begin{array}{l}3,365 \\
3,321 \\
3,308 \\
3,253 \\
3,275 \\
3,256 \\
3,239 \\
3,219 \\
3,208 \\
3,191 \\
3,183 \\
3,167 \\
3,148 \\
3,143 \\
3,144 \\
3,141 \\
3,148 \\
3,146\end{array}$ \\
\hline
\end{tabular}

creasing tendency during the next three years was followed by a significant increase partly as the consequence of certain demographic-political measures and partly because female cohorts born after the second world war were reaching reproductive age (Szabady, 1968). The turning point in 1962 is worth noting in relation to the birth weight changes. The mean birth weight decreased until 1962 and then showed little change. The proportion of low-weight births increased rapidly until 1962 and then increased more slowly. The relation of birth rate to birth weight changes is more obvious when data for the capital, Budapest, are examined (Fig. 4).

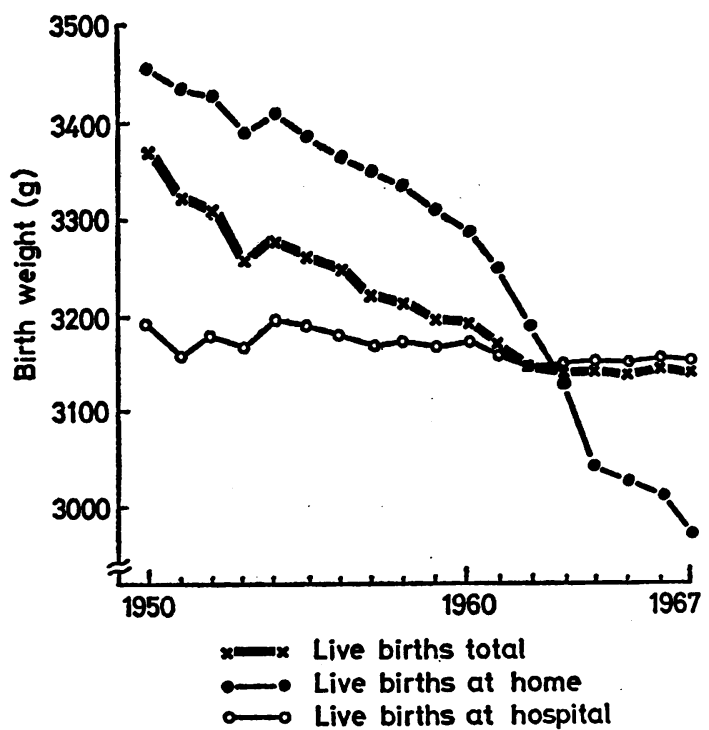

FIG. 1. Changes in mean birth weight in Hungary between 1950 and 1967.
The incidence of induced abortions showed an exponential increase between 1956 and 1964 and a slighter increase after 1964 (Fig. 3). The figures for the years before 1956 are not reliable because of the unknown number of criminal interruptions, but they almost certainly under-estimate the true frequency.

The changes in mean birth weight and in the proportion of low-weight births in Hungary recorded above are, to some extent, the result of changes in methods of birth registration and, perhaps, to greater accuracy of weighing. Other reasons for the changes which will be considered are demographic and social.

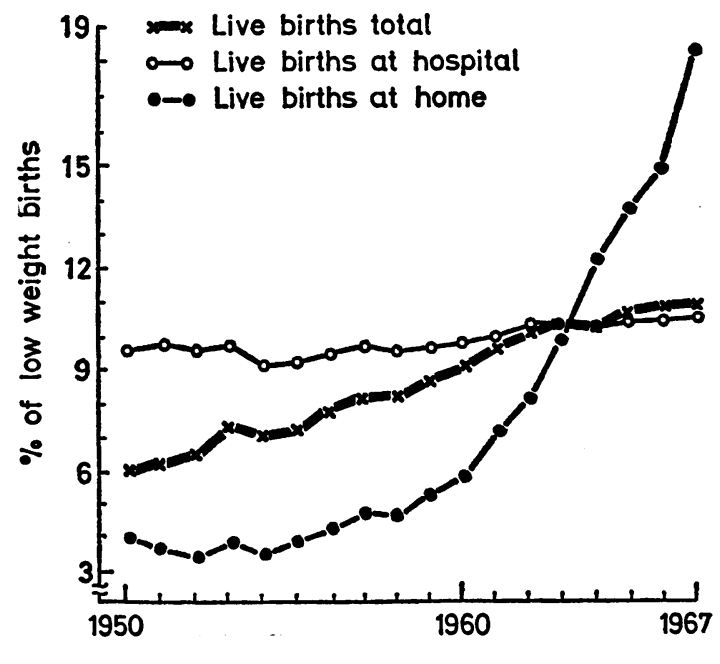

Fig. 2. Changes in the proportion of low-weight births in Hungary between 1950 and 1967. 


\section{Changes in Registration}

Previously, live births weighing less than $1,000 \mathrm{~g}$. tended to be classified as abortus fetuses. They are now registered as live births of low birth weight. Furthermore, improving standards of obstetric care increase the chance of these small fetuses being born alive. In 1950 only $0.16 \%$ of all live births and $2.8 \%$ of low-weight births weighed less than $1,000 \mathrm{~g}$. In 1967 the respective proportions were $0.69 \%$ and $6.4 \%$.

Distinction between live and still births may sometimes be difficult and in certain cases may depend on the view of the obstetrician. Evidence for this is provided in Fig. 5 where components of perinatal mortality in some European countries are shown (World Health Organization, 1969). The still birth rate in Hungary is lower than in most countries but mortality during the first week after birth is one of the highest in Europe, and mortality on the first day is outstandingly high $(14.0$ per 1,000$)$. It is clear that different criteria are used in different countries in distinguishing between live and still births, possibly because of the greater benefits (such as maternity allowances, maternity leave, and tax concessions) available in some countries in cases of live births. Thus a number of births that would be considered fetal deaths in other European countries are classified as live births in Hungary. The validity of this assumption is supported by the results of our studies on anencephalics (Czeizel and Révész, 1970). In most countries the majority of anencephalics are still born. In South Wales, for example, only $3 \%$ of anencephalics were live born (Laurence, Carter, and David, 1968). In Hungary, however, $26 \%$ of the

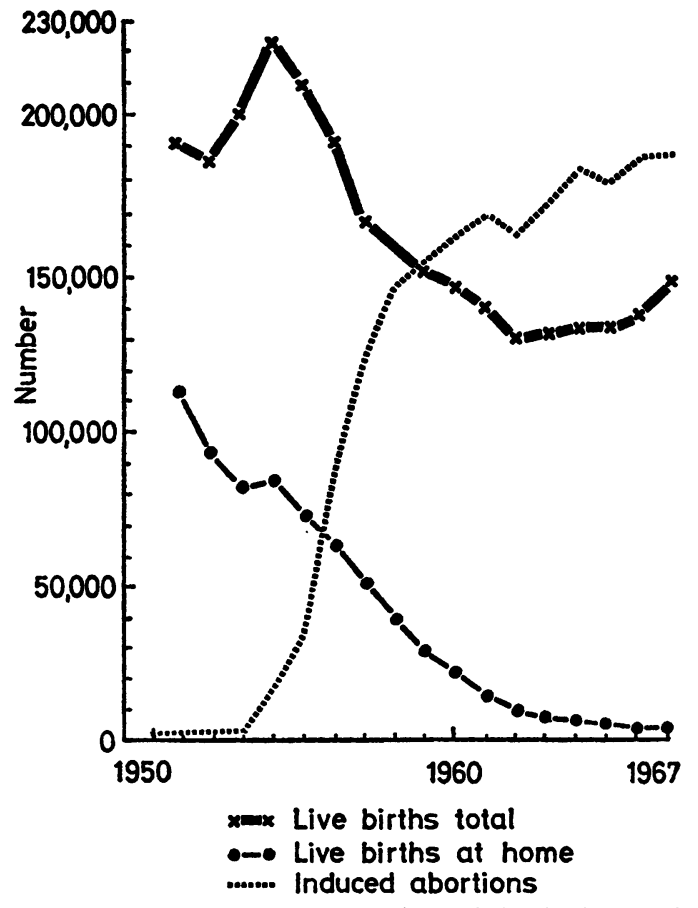

Fig. 3. Annual numbers of live births in hospital and at home and

anencephalics born in the period 1963-67 were live $\stackrel{?}{\%}$ born, and $76 \%$ weighed less than $2,500 \mathrm{~g}$. at birth. Uncertainties in the distinction between live births and still births also affect the frequency of lowweight births, as $84.7 \%$ of the first day deaths occurred in infants weighing less than $2,500 \mathrm{~g}$.

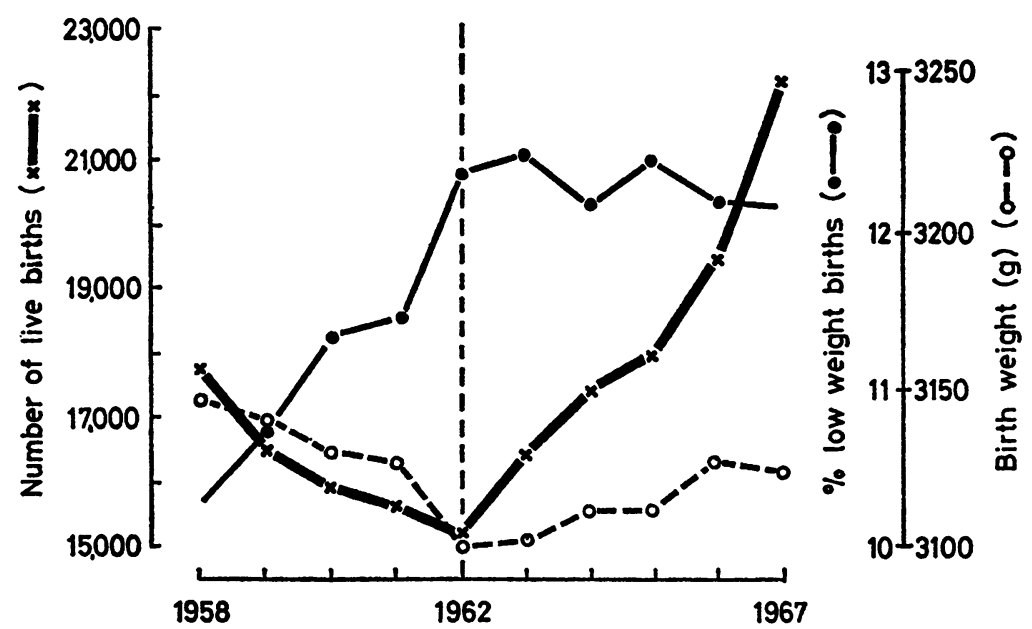

FIG. 4. Annual numbers of live births, mean birth weight, and proportion of low-weight births in Budapest between 1958 and 1967. 


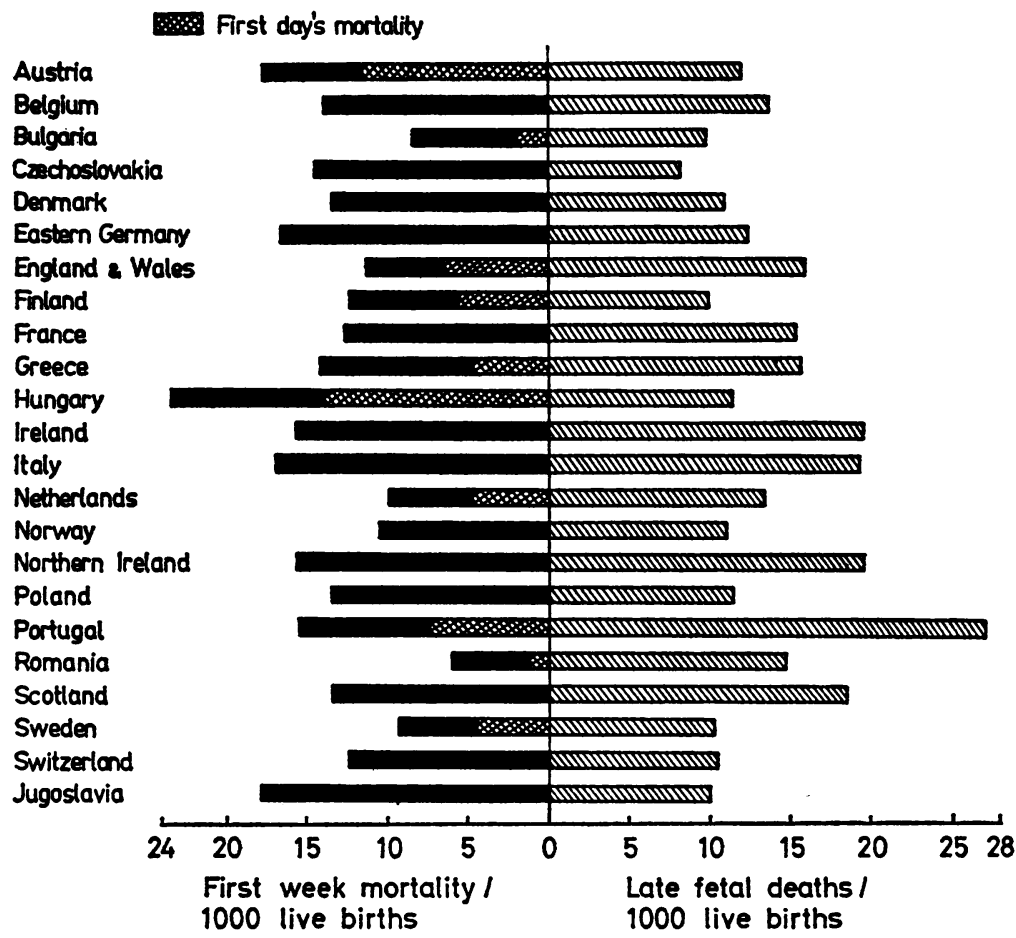

Fio. 5. Perinatal mortality divided into late fetal (still birth) mortality and first-week mortality in various European countries in 1965.

\section{ACCURACY OF WEIGHING}

The mean birth weight was 3,361g. in 1950 and $3,146 \mathrm{~g}$. in 1967-a decrease of 215g.- but for those born in hospital the mean decreased by only $38 \mathrm{~g}$. (from 3,189g. to 3,151g.) (Fig. 1). Weighing in hospital is undoubtedly more reliable than weighing at home, and it is likely that the weights recorded at home tended to be over-estimates. It is possible, therefore, that the increasing number of deliveries in hospital and the consequent greater reliability of weight recording may have contributed to the fall in mean birth weight.

The considerable decrease in the mean weight of children born at home (from 3,456g. in 1950 to 2,976g. in 1967) deserves some comment. Earlier, primiparae and pregnant women threatened with complications would have gone to hospital and women having their second and further children would generally have been delivered at home. Today the number of deliveries occurring out of hospital is extremely small (less than $3 \%$ ) and probably consists largely of cases where labour occurred prematurely so that there was not time enough for admission to hospital. The high proportion of low-weight births $(18.4 \%$ in 1967$)$ is consistent with this explanation.

If attention is restricted to hospital births, it is seen that the mean birth weight stayed essentially on the same level between 1950 and 1967 (Fig. 1). The proportion of low-weight births was $9.6 \%$ in 1950 and $10.6 \%$ in 1967 . This $1 \%$ difference can be attributed mainly to the increased proportion of births weighing under $1,000 \mathrm{~g}$.

\section{Demographic Changes}

It has been known for some time that there is a correlation between the age of mothers at delivery and the birth weight of their children. This correlation is well exemplified by the 1957 Hungarian data (Fig. 6) which show that mothers under 20 have infants with birth weights well below average. The highest mean weight is shown by the age group 25-35. These facts are mentioned because the proportion of births to mothers under 20 increased from $9.3 \%$ in 1948 to $13.6 \%$ in 1966 . This may account for some of the decrease in mean birth weight. But it can be seen that for mothers of all ages over 25 mean birth weights were lower in 1967 than in 1957. Another interesting difference between the two years is that now the mean weight is highest for women of about 25 whereas 10 years ago the greatest weights were attained by women of 35 .

Much of this age effect is, of course, due to the 


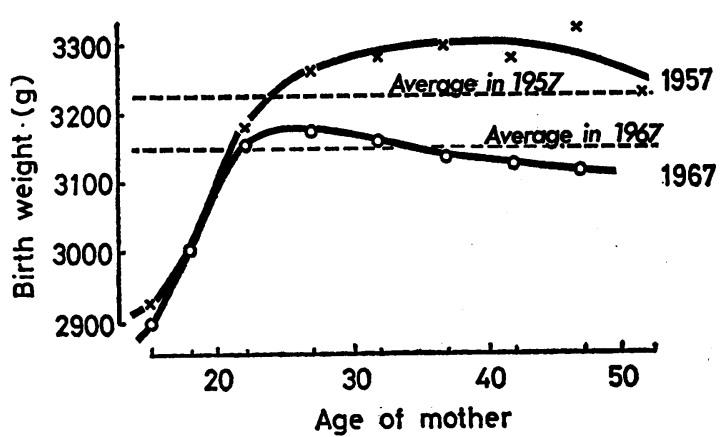

Fig. 6. Mean birth weight according to age of mother at birth in Hungary in 1957 and in 1967.

correlation between age of mother and birth order (Czeizel, Tusnády, and Domány, 1969). It is well known that the average weight of first-born babies is less than that of second-born babies, and the mean increases further with advancing birth order. Both the 1954 and the 1959 Hungarian data illustrate this (Fig. 7 and Table III). The growing practice of birth control results in a higher proportion of first-born in the total number of births. This proportion was $30 \%$ in $1930,35.3 \%$ in $1954,43.5 \%$ in 1958 , and $49.0 \%$ in $1966-67$. The increased proportion of first-born with their lower birth weight would tend to lower the national mean birth weight. We estimate that the increase in the proportion of first births between 1954 and 1967 could account for a $0.5 \%$ increase in the incidence of births of low weight. More important, however, is the change in the relationship of birth weight and birth order. In 1967,

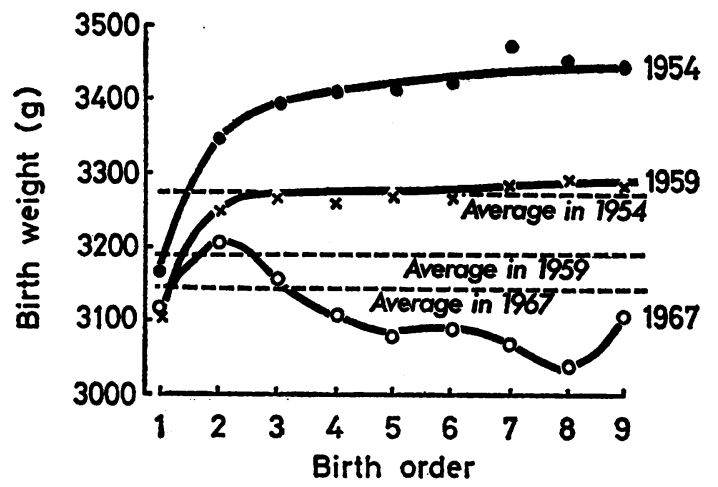

FIG. 7. Mean birth weight according to birth order in Hungary in 1954, 1959, and 1967.

the weight of third-born infants was less than that of second-born and weights of infants of higher birth orders were even lower. At present, the weights of $\vec{\sigma}$ fourth, fifth, sixth, and further births are below the $ᄋ$ national average. This effect is even more obvious when the proportions of low-weight births are plotted (Fig. 8). In 1954 and 1959 the frequency of low-weight births was high in first-born and low in second and subsequent births. A considerable changs $\overrightarrow{0}$ had occurred by 1967. Though the frequency wa lower in second births than in first births, it was. much higher in all births after the second.

\section{Significance of Differential Family Planning}

When attempting to explain the changes in birth weight which we have described, it is necessary to consider two well-known points:

1. There is a correlation between birth weight and

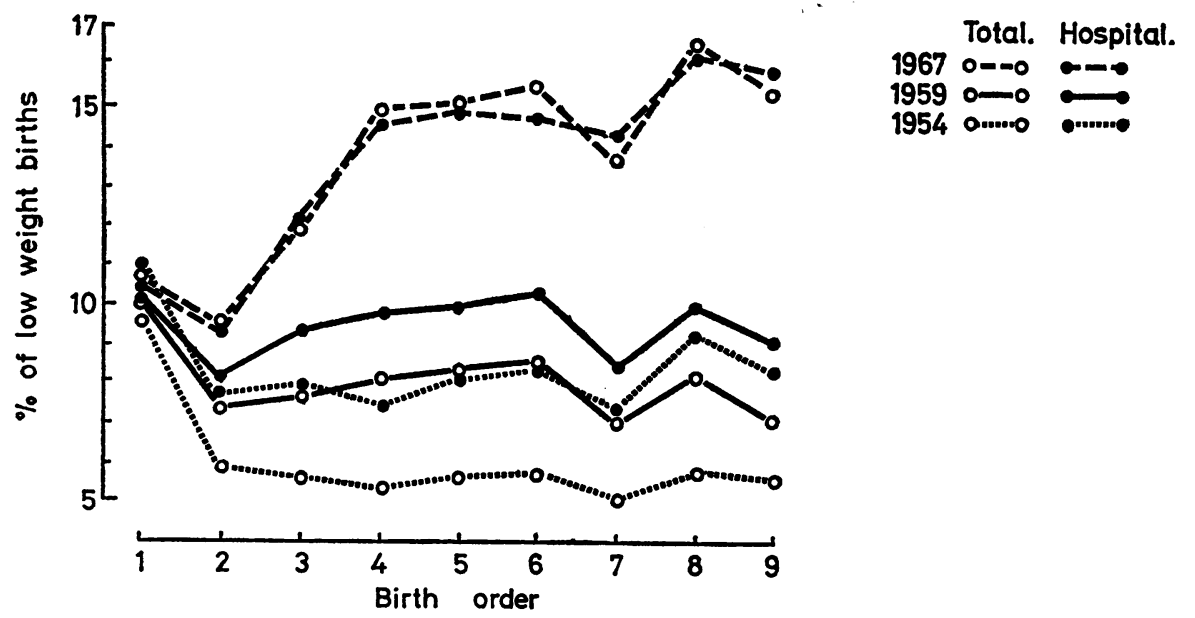

FIG. 8. Proportion of low-weight births according to birth order in_Hungary in 1954, 1959, and 1967. 
TABLE III

CHANGES IN NUMBER OF LIVE BIRTHS, MEAN BIRTH WEIGHT AND PERCENTAGE INCIDENCE OF LOW-WEIGHT BIRTHS IN RELATION TO BIRTH ORDER IN HUNGARY, 1953-54, AND 1959-67

\begin{tabular}{|c|c|c|c|c|c|c|c|c|c|c|c|}
\hline Year & 1 & 2 & 3 & 4 & ${ }_{5}^{\text {Bi }}$ & $\begin{array}{r}\text { rder } \\
6\end{array}$ & 7 & 8 & 9 & $10+$ & Total \\
\hline \multirow[b]{2}{*}{$\begin{array}{l}1953 \\
1954\end{array}$} & \multicolumn{2}{|c|}{ No. of live births } & & & & & & & & & \\
\hline & \multirow{7}{*}{$\begin{array}{r}77,751 \\
78,880 \\
(58,530) \\
66,353 \\
(59,728) \\
64,403 \\
63,153 \\
59,084 \\
59,596 \\
62,823 \\
64,892 \\
68,238 \\
72,504 \\
(71,998)\end{array}$} & $\begin{array}{l}58,733 \\
66,503\end{array}$ & $\begin{array}{l}31,963 \\
35,318\end{array}$ & $\begin{array}{l}16,135 \\
18,253\end{array}$ & $\begin{array}{l}\mathbf{8 , 5 3 4} \\
\mathbf{9 , 5 8 2}\end{array}$ & $\begin{array}{l}\mathbf{4}, 857 \\
5,482\end{array}$ & $\begin{array}{l}\mathbf{3}, 098 \\
\mathbf{3 , 3 4 3}\end{array}$ & $\begin{array}{l}2,106 \\
2,235\end{array}$ & $\begin{array}{l}1,417 \\
1,387\end{array}$ & $\begin{array}{l}2,332 \\
2,364\end{array}$ & $\begin{array}{r}206,926 \\
223,347\end{array}$ \\
\hline 1959 & & $\begin{array}{r}(40,558) \\
45,113\end{array}$ & $\begin{array}{l}(19,416) \\
18,170\end{array}$ & $\begin{array}{l}(9,251) \\
8,682\end{array}$ & $\begin{array}{l}(4,662) \\
4,735\end{array}$ & $\begin{array}{l}(2,548) \\
2,998\end{array}$ & $\begin{array}{l}(1,577) \\
1,970\end{array}$ & 1,231 & $\begin{array}{c}(1.146) \\
781\end{array}$ & $\begin{array}{l}(653) \\
1,161\end{array}$ & $\begin{array}{l}(139,337) \\
151,194\end{array}$ \\
\hline \multirow{5}{*}{$\begin{array}{l}1960 \\
1961 \\
1962 \\
1963 \\
1964 \\
1965 \\
1966 \\
1967\end{array}$} & & $\left(\begin{array}{ll}34,663) \\
4969\end{array}\right.$ & $(12,793)$ & $(5,787)$ & $(3,061)$ & $(1,956)$ & $(1,219)$ & (775) & (522) & (741) & $(121,245)$ \\
\hline & & $\begin{array}{l}42,909 \\
40,795 \\
37,681 \\
39,956\end{array}$ & $\begin{array}{l}18,030 \\
17,264 \\
15,593 \\
15,338\end{array}$ & $\begin{array}{l}8,790 \\
7,844 \\
7,264 \\
7,076\end{array}$ & $\begin{array}{l}4,021 \\
4,214 \\
3,819 \\
3,886\end{array}$ & $\begin{array}{l}2,619 \\
2,402 \\
\mathbf{2 , 3 5 9}\end{array}$ & $\begin{array}{r}1,803 \\
1,695 \\
1,550 \\
1,524\end{array}$ & $\begin{array}{l}1,099 \\
1,060 \\
1,019\end{array}$ & $\begin{array}{l}675 \\
626 \\
621\end{array}$ & $\begin{array}{r}1,007 \\
9974 \\
960\end{array}$ & $\begin{array}{l}140,401 \\
140,365 \\
130,053 \\
132,335\end{array}$ \\
\hline & & $\begin{array}{l}39,956 \\
39,199 \\
30,770\end{array}$ & $\begin{array}{l}15,338 \\
14,260 \\
14,470\end{array}$ & $\begin{array}{l}7,076 \\
6,516\end{array}$ & $\begin{array}{l}3,886 \\
3,455\end{array}$ & $\begin{array}{l}2,359 \\
2,119\end{array}$ & $\begin{array}{l}1,324 \\
1,438\end{array}$ & $\begin{array}{r}1,019 \\
910 \\
872\end{array}$ & $\begin{array}{l}541 \\
549 \\
554\end{array}$ & $\begin{array}{l}900 \\
872\end{array}$ & 132,141 \\
\hline & & $\begin{array}{l}39,770 \\
42,957\end{array}$ & $\begin{array}{l}13,472 \\
12,782\end{array}$ & $\begin{array}{r}5,982 \\
5,799\end{array}$ & $\begin{array}{l}3,316 \\
3,250\end{array}$ & $\begin{array}{l}2,172 \\
2,028\end{array}$ & $\begin{array}{l}1,324 \\
1,248\end{array}$ & $\begin{array}{l}826 \\
867\end{array}$ & $\begin{array}{l}344 \\
516\end{array}$ & 804 & $\begin{array}{r}138,489 \\
138,489\end{array}$ \\
\hline & & $\begin{array}{r}48,343 \\
(47,176)\end{array}$ & $\begin{array}{l}13,705 \\
(13,077)\end{array}$ & $\begin{array}{r}5,777 \\
(5,337)\end{array}$ & $\begin{array}{r}3,071 \\
(3,071)\end{array}$ & $\begin{array}{r}2,039 \\
(1,807)\end{array}$ & $\begin{array}{l}1,271 \\
(1,118)\end{array}$ & $\begin{array}{l}868 \\
(756)\end{array}$ & $\begin{array}{l}515 \\
(447)\end{array}$ & $\begin{array}{l}793 \\
(663)\end{array}$ & $\begin{array}{l}1485,886 \\
(145,156)\end{array}$ \\
\hline \multirow{3}{*}{$\begin{array}{l}1953 \\
1954\end{array}$} & \multicolumn{3}{|c|}{ Mean birth weight (g.) } & & & & & & & & \\
\hline & \multirow{10}{*}{$\begin{array}{r}3,164 \\
3,167 \\
(3,108) \\
3,105 \\
(3,096) \\
3,106 \\
3,098 \\
3,080 \\
3,089 \\
3,096 \\
3,102 \\
3,114 \\
3,116 \\
(3,120)\end{array}$} & & 3,341 & 3,351 & 3,36 & $\mathbf{3 , 3 4 7}$ & 3,36 & 3,389 & 3,37 & 3,368 & 3,253 \\
\hline & & $\begin{array}{l}3,348 \\
(3,266)\end{array}$ & $\begin{array}{l}3,396 \\
(3,297)\end{array}$ & $\begin{array}{l}3,413 \\
(3,327)\end{array}$ & $\begin{array}{l}3,416 \\
(3,322)\end{array}$ & $\begin{array}{l}3,425 \\
(3,316)\end{array}$ & $\begin{array}{l}3,475 \\
(3,390)\end{array}$ & $\begin{array}{l}3,453 \\
(3,356)\end{array}$ & $\begin{array}{l}3,443 \\
(3,366)\end{array}$ & $(3,364)$ & $(3,218)$ \\
\hline 1959 & & 3,252 & 3,267 & 3,260 & 3,268 & 3,265 & 3,282 & 3,293 & 3,284 & 3,263 & 3,191 \\
\hline \multirow{7}{*}{$\begin{array}{l}1960 \\
1961 \\
1962 \\
1963 \\
1964 \\
1965 \\
1966 \\
1967\end{array}$} & & $\begin{array}{l}(3,227) \\
3,240\end{array}$ & $(3,229)$ & $\begin{array}{l}(3,235) \\
3,250\end{array}$ & $(3,225)$ & $(3,226)$ & $(3,247)$ & $(3,252)$ & $(3,256)$ & $(3,240)$ & $(3,163)$ \\
\hline & & $\begin{array}{l}3,230 \\
3,208\end{array}$ & 3,240 & 3,215 & 3,177 & 3,215 & 3,201 & 3,192 & 3,196 & 3,225 & 3,167 \\
\hline & & $\begin{array}{l}3,208 \\
3,200\end{array}$ & $\begin{array}{l}3,199 \\
3,186\end{array}$ & $\begin{array}{l}3,180 \\
3,160\end{array}$ & $\begin{array}{l}3,168 \\
3,162\end{array}$ & $\begin{array}{l}3,160 \\
3,161\end{array}$ & 3,160 & $\begin{array}{l}3,169 \\
3,175\end{array}$ & $\begin{array}{l}3,150 \\
3,161\end{array}$ & $\begin{array}{l}3,154 \\
3,154\end{array}$ & $\begin{array}{l}3,148 \\
3,143\end{array}$ \\
\hline & & 3,206 & 3,179 & 3,156 & 3,136 & 3,137 & 3,135 & 3,161 & 3,184 & 3,143 & 3,144 \\
\hline & & $\begin{array}{l}3,204 \\
3.209\end{array}$ & 3,164 & 3,120 & 3,114 & 3,104 & 3,107 & 3,115 & 3,192 & 3,167 & 3,141 \\
\hline & & 3,206 & 3,154 & 3,108 & 3,082 & 3,085 & 3,068 & 3,039 & 3,109 & 3,086 & 3,146 \\
\hline & & $(3,209)$ & $(3,160)$ & $(3,116)$ & $(3,092)$ & $(3,103)$ & $(3,070)$ & $(3,052)$ & $(3,141)$ & $(3,141)$ & $(3,150)$ \\
\hline \multirow{3}{*}{$\begin{array}{l}1953 \\
1954\end{array}$} & \multicolumn{4}{|c|}{ Percentage incidence of low-weight births } & & & & & & & \\
\hline & \multirow{9}{*}{$\begin{array}{c}\text { rercent } \\
9.44 \\
9.44 \\
(10.95) \\
10.29 \\
(10.56) \\
10.37 \\
10.82 \\
10.92 \\
10.91 \\
10.77 \\
10.76 \\
10.66 \\
10.58 \\
(10.42)\end{array}$} & & & 5.97 & & $6 \cdot 55$ & 5.84 & & & $6 \cdot 1$ & \\
\hline & & $\begin{array}{c}5.89 \\
(7.75)\end{array}$ & $\begin{array}{c}5.544 \\
(7.83)\end{array}$ & $(7.41)$ & $\begin{array}{l}5.51 \\
(8.07)\end{array}$ & $\begin{array}{r}5.56 \\
(8.40)\end{array}$ & $\begin{array}{l}4.97 \\
(7.29)\end{array}$ & $(9 \cdot 64)$ & $\begin{array}{r}5.48 \\
(8.27)\end{array}$ & $\begin{array}{r}5.92 \\
(15.77)\end{array}$ & $\begin{array}{l}7 \cdot 00 \\
(9 \cdot 12)\end{array}$ \\
\hline 1959 & & 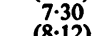 & $\begin{array}{l}7.72 \\
0.977\end{array}$ & $\begin{array}{l}8.08 \\
0.78)\end{array}$ & $\begin{array}{l}8.20 \\
0.87\end{array}$ & $\begin{array}{r}8.45 \\
0\end{array}$ & 6.96 & 8.13 & 7.05 & $11 \cdot 37$ & $\begin{array}{l}8.78 \\
(9.64)\end{array}$ \\
\hline \multirow{6}{*}{$\begin{array}{l}1960 \\
1961 \\
1962 \\
1963 \\
1964 \\
1965 \\
1966 \\
1967\end{array}$} & & $\begin{array}{l}7.79 \\
8.21\end{array}$ & $\begin{array}{l}8.50 \\
8.42\end{array}$ & $\begin{array}{r}8.39 \\
10.06\end{array}$ & $\begin{array}{r}9.01 \\
10.54\end{array}$ & $\begin{array}{c}9.72 \\
9.55\end{array}$ & $\begin{array}{l}8.66 \\
9.79\end{array}$ & $\begin{array}{r}8.72 \\
10.75\end{array}$ & $\begin{array}{l}10.32 \\
12.15\end{array}$ & $\begin{array}{l}10.66 \\
10.22\end{array}$ & $\begin{array}{l}9.17 \\
9.68\end{array}$ \\
\hline & & 8.72 & $\begin{array}{l}8.52 \\
9.52\end{array}$ & $\begin{array}{l}10.06 \\
10.60\end{array}$ & $\begin{array}{l}10.54 \\
11.21\end{array}$ & $\begin{array}{r}9 \cdot 55 \\
11 \cdot 41\end{array}$ & $\begin{array}{l}9.79 \\
8.84\end{array}-1010$ & $\begin{array}{l}10.75 \\
11 \cdot 42\end{array}$ & $\begin{array}{l}12 \cdot 15 \\
12.78\end{array}$ & $\begin{array}{l}10.22 \\
11.80\end{array}$ & $\begin{array}{c}9 \cdot 68 \\
10 \cdot 11\end{array}$ \\
\hline & & 8.90 & 10.55 & $11 \cdot 35$ & 11.09 & 11.08 & 12.48 & 11.38 & 12.24 & 13.02 & $10 \cdot 33$ \\
\hline & & $9 \cdot 18$ & $\begin{array}{l}10.67 \\
11.56\end{array}$ & 1134 & 13.30 & 13.58 & $\begin{array}{l}12.00 \\
15.03\end{array}$ & $\begin{array}{l}11.35 \\
12.97\end{array}$ & $\begin{array}{l}13.21 \\
9.56\end{array}$ & $\begin{array}{l}12.50 \\
11.53\end{array}$ & $\begin{array}{l}10.35 \\
10.61\end{array}$ \\
\hline & & $9 \cdot 35$ & 11.66 & 12.61 & 11.42 & 15.29 & 13.06 & 13.38 & $13 \cdot 1$ & 17.16 & 10.67 \\
\hline & & & $(12.06)$ & (14.58) & $(14.98)$ & $\begin{array}{l}13.46 \\
(14.67)\end{array}$ & $\begin{array}{l}(13.69) \\
(14.22)\end{array}$ & $\begin{array}{l}16.59 \\
(16.27)\end{array}$ & $(15.88)$ & $\begin{array}{l}16.15 \\
(15.83)\end{array}$ & $(10.61)$ \\
\hline
\end{tabular}

Figures in brackets relate to hospital births.

socio-economic status. Within a race, the higher the living standard, the higher is the mean birth weight and the lower the frequency of low-weight births (Baird, 1962; Donnelly, Flowers, Creadick, Wells, Greenberg, and Surles, 1964).

2. Families living under poor social, economic, and cultural conditions usually show a higher birth rate than those living under easier conditions and having a better educational background.

In Hungary parents now wish to have fewer children than formerly. At the same time a primitive method of birth control, viz., artificial termination of pregnancy, has become generally available. The rapidly growing claim for birth control and the available methods resulted by 1962 in a decrease in birth rate to a low level never experienced before in Hungary. A parallel change in the social, economic, and cultural level of the families producing the new generation had occurred (Hirschler, 1967). At present, families with 4 to 10 children generally belong to the poorest and least educated social strata. These families do not yet realize the possibility of using birth control methods-not even artificial interruption of pregnancy (Acsády, 1967; Szabady, 1967). The birth weight of their children is below average, mainly as a consequence of their poor economic circumstances. The gipsy population illustrates this point. While the crude birth rate for the whole population of Hungary was 14.4 per 1,000 in 1960-61 it was 40.9 per 1,000 in the gipsy population in the Sellye county (Hooz, 1964). The mean birth weight of gipsy infants was 2,961g.; for nongipsy infants in the same area it was $3,213 \mathrm{~g}$. A similar difference was found in the frequency of low-weight births, the proportions being $15.0 \%$ and $8.5 \%$ respectively. The population of gipsies in 
Hungary is estimated to be about 200,000 , i.e., about $2 \%$ of the population, but owing to their high birth rate, the proportion of gipsy births is much higher than $2 \%$. It should be emphasized that these figures based on a gipsy population are given only as an example and that similar cultural and economic conditions could be found also in a certain proportion of the non-gipsy population.

In summary, at some risk of over-simplifying the problem, one can postulate the existence of two population groups. The larger one consists of wellto-do and well-educated people and produces 'large' babies. The other is poor and less educated and produces 'small' babies. At one time the first group produced a good proportion of third, fourth and later children who were, on average, heavier than first-born, but in recent years because of increasing use of birth control methods the proportion of later born produced by this population group has substantially declined, while the second group has continued to produce their smaller babies at an almost unchanged rate. This accounts for some of the decrease in the mean birth weight for the whole country.

\section{CONCLUSION}

Birth weight is dependent on a number of genetic and environmental factors (Bognár and Czeizel, 1970), but in this paper we have restricted attention to those which apply particularly to Hungary.

Distorting factors connected with the diagnosis and registration of live births may have a considerable effect on mean birth weight and on the frequency of low-weight births. The low still birth rate and the high rate of mortality on the first day in Hungary suggests that many fetuses which would be regarded elsewhere as still births are here registered as live births and, because of their low weight, contribute to a lowering of the mean birth weight for the country. It is probable that the accuracy of weighing is improving because nearly all births now take place in hospital where weights are more accurately recorded than at home, and this might account for a slight fall in mean birth weight. Mean birth weight has increased in countries with high or rising living standards (e.g., Sweden and Japan) during the last decade. Changes in nutritional and social conditions that have occurred during the past 10 years should have led to an increase also in Hungary. The failure to show an increase in birth weight can be attributed primarily to family planning. The adverse effects of this on birth weight acted in three ways:

1. The methods of birth control are used primarily by that population which lives under easier socioeconomic conditions whose children have higher birth weights. On the other hand, the population living at a lower environmental and cultural level, which produces babies with lower weights, hardly ever makes use of birth control methods. The high reproduction rate of the second group thus has a lowering influence on the mean birth weight of the whole population.

2. The most widely used method of birth control has been the artificial termination of pregnancy. Evidence that this practice may lead to premature termination of subsequent pregnancies has been put $\mathrm{c}$ forward by Barsy and Sárkány (1963). It has been $\vec{\circ}$ shown that in Budapest about $12 \%$ of low-weight $\overrightarrow{\vec{H}}$ births (and about $4 \%$ in the country as a whole) could be traced back to earlier induced abortions (Miltényi, 1964).

3. Increasing use of birth control methods has resulted in a growing proportion of first births which $\stackrel{\oplus}{\omega}$ have lower weights than later births. About half the $\overrightarrow{\vec{A}}$ births in 1967 were first births. It is estimated that $\vec{D}$ this effect alone increased the percentage of low- 은 weight births by 0.5 .

\section{SUMMARY}

The proportion of low-weight births in Hungary $(10.8 \%$ in 1967$)$ is much higher than in othe $\vec{\theta}$ European countries. This high incidence is attributer partly to the more accurate registration of birth. weighing less than $1,000 \mathrm{~g}$., to uncertainty in dis tinguishing between live births and still births, and to increasing accuracy of weighing due to the fact that nearly all births now occur in hospital. Some of the increase is also due to social class differences in the use of family planning. Parents living on a lower environmental and cultural level who are likely to produce infants of low weights hardly ever use birth control methods, whereas people in better circumstances who would have infants of higher weights use them more frequently. Furthermore, the most widely used method of birth control in Hungary is artificial interruption of pregnancy which, it is suggested, may cause subsequent pregnancies to terminate prematurely. Finally, increasing use of birth control is causing an increase in the relative numbers of first births, which have lower birth weights than later born infants.

\section{REFERENCES} AcsÁDY, G. (1967). Demographic table methods for
measuring fertility trends. Demográfia, 10, 188 .

BAIRD, D. (1962). Environmental and obstetrical factors in prematurity, with special reference to experience in Aberdeen. Bull. Wld Hlth Org., 26, 291.

BARSY, G., and SÁRKÁNY, J. (1963). Impact of induced abortion on the birth. Demográfia, 6, 427. 
BognÁr, Z., and CZEizel, E. (1970). Share of known noxae in the etiology of low birth weights. Orvosképzés. In press.

Czeizel, E., and Révész, K. (1970). The incidence of neural tube defects in Budapest. Gyermekgy ógyászat. In press.

- -, TUSNÁDY, G., and DoMÁNY, Z. (1969). The genetical consequences of family planning. Orv. Hetil., 110, 2993.

Donnelly, J. F., Flowers, C. E., Creadick, R. N., Wells, H. B., Greenberg, B. G., and Surles, K. B. Maternal, fetal, and environmental factors in prematurity. Amer. J. Obstet. Gynec., 88, 918.

HiRSCHLER, I. (1967). Obstetrical aspects of perinatal mortality. In Prae-és perinatalis kérdések. p. 86. If jusági Lapkiadó Váll, Budapest.
Hooz, I. (1964). Birth characteristics of the gipsies in the Sellye district. Demográfia, 7, 230.

Laurence, K. M., Carter, C. O., and David, P. A. (1968). Major central nervous system malformations in South Wales. II Pregnancy factors, seasonal variation, and social class effects. Brit. J. prev. soc. Med., 22, 212.

MiLTÉNYI, K. (1964). Demographic significance of induced abortion. Demográfia, 7, 419.

Szabady, E. (1967). Family planning. Demográfia, 10, 219.

(1968). Family planning trends: the Hungarian study. Demográfia, 11, 333.

World Health Organization (1969). Perinatal Mortality, 22, No. 1, 42. 